\title{
Ultrastructural Evidence for Prominent Distribution of the $\mu$-Opioid Receptor at Extrasynaptic Sites on Noradrenergic Dendrites in the Rat Nucleus Locus Coeruleus
}

\author{
Elisabeth J. Van Bockstaele, ${ }^{1}$ Eric E. O. Colago, ${ }^{1}$ Peter Cheng, ${ }^{1}$ Akiyoshi Moriwaki, ${ }^{2}$ George R. Uhl, ${ }^{2}$ and \\ Virginia M. Pickel ${ }^{1}$ \\ ${ }_{1}^{1}$ Department of Neurology and Neuroscience, Cornell University Medical College, New York, New York 10021, and \\ 2National Institute on Drug Abuse, Division of Intramural Research Program, Addiction Research Center, \\ Baltimore, Maryland 21224
}

Physiological studies have indicated that agonists at the $\mu$-opioid receptor $(\mu \mathrm{OR})$, such as morphine or the endogenous peptide methionine ${ }^{5}$-enkephalin, can markedly decrease the spontaneous activity of noradrenergic neurons in the locus coeruleus (LC). Messenger RNA and protein for $\mu \mathrm{OR}$ are also densely expressed by LC neurons. During opiate withdrawal, increased discharge rates of LC neurons coincide with the expression of behavioral features associated with the opiate withdrawal syndrome. To better define the cellular sites for the physiological activation of $\mu \mathrm{OR}$ in the $\mathrm{LC}$ and its relation to afferent terminals, we examined the ultrastructural localization of $\mu \mathrm{OR}$ immunoreactivity in sections dually labeled for the catecholamine-synthesizing enzyme tyrosine hydroxylase (TH). Immunogold-silver labeling for $\mu \mathrm{OR}(\mathrm{i}-\mu \mathrm{OR})$ was localized to parasynaptic and extrasynaptic portions of the plasma membranes of perikarya and dendrites, many of which also contained immunolabeling for $\mathrm{TH}$. The dendrites containing exclusively $\mathrm{i}-\mu \mathrm{OR}$ were more numerous in the rostral pole of the LC. The $\mathrm{i}-\mu \mathrm{OR}$ in dendrites with and without detectable $\mathrm{TH}$ immunoreactivity were usually postsynaptic to unlabeled axon terminals containing heterogeneous types of synaptic vesicles and forming asymmetric synaptic specializations characteristic of excitatory-type synapses. These results provide the first direct ultrastructural evidence that $\mu \mathrm{OR}$ is strategically localized to modulate the postsynaptic excitatory responses of catecholamine-containing neurons in the LC.

Key words: norepinephrine; drug abuse; enkephalin; opiate; morphine; excitatory amino acid
Norepinephrine-containing neurons in the nucleus locus coeruleus (LC) are densely innervated by processes containing endogenous opioid peptides (Simantov et al., 1977; Pickel et al., 1979; Khachaturian et al., 1983; Fallon and Leslie, 1986; Drolet et al., 1992). A significant portion of this opioid innervation derives from opioid-containing neurons in the nucleus paragigantocellularis (PGi) in the rostral ventral medulla (Drolet et al., 1992). We have also shown recently (Van Bockstaele et al., 1995) that morphologically heterogenous terminals containing methionine ${ }^{5}$-ENK form synapses with neurons in the LC that are immunoreactive for the catecholamine-synthesizing enzyme tyrosine hydroxylase (TH). Ligand autoradiographic studies, in situ hybridization, and light microscopic immunocytochemistry each have shown that the LC region contains a high concentration of $\mu$-opioid receptors ( $\mu$ ORs) (Atweh and Kuhar, 1977; Tempel and Zukin, 1987; Arvidsson et al., 1995; Mansour et al., 1995). Activation of LC $\mu$ ORs by the opioid peptides or by opiate drugs potently decreases the spontaneous activity of LC neurons (Bird and Kuhar, 1977; Pepper and Henderson, 1980; Williams et al., 1982; Harris and Williams, 1991; Alreja and Aghajanian, 1993). The acute

\footnotetext{
Received Feb. 6, 1996; revised May 9, 1996; accepted May 21, 1996.

This work was supported by a National Association for Research on Schizophrenia and Depression Young Investigator Award and National Institute on Drug Abuse (NIDA) Grant R29 DA09082 to E.J.V.B. and National Institute of Mental Health Grants MH40342 and MH00078 and NIDA DA04600 to V.M.P. We gratefully acknowledge the photographic assistance of Ms. Joy Hornung.

Correspondence should be addressed to Dr. Elisabeth J. Van Bockstaele, Division of Neurobiology, Cornell University Medical College, 411 East 69th Street, Room KB410, New York, NY 10021.

Copyright (C) 1996 Society for Neuroscience $0270-6474 / 96 / 165037-12 \$ 05.00 / 0$
}

inhibition of LC neurons by opiates is mediated by an activation of an inwardly rectifying potassium channel via a pertussis toxinsensitive G-protein (North and Williams, 1985; Aghajanian and Wang, 1986). Acute opiate treatment also inhibits LC adenylate cyclase activity (Duman et al., 1988; Beitner et al., 1989) and decreases cAMP-dependent protein phosphorylation (Guitart and Nestler, 1989, 1993; Nestler et al., 1989a,b). These results suggest that methionine ${ }^{5}$-ENK may be an endogenous ligand for the intensely distributed opioid receptors in this region and that pharmacological occupancy of these receptors by opiate drugs may contribute significantly to clinically important aspects of the opiate withdrawal syndrome. The subcellular sites for the physiological effects of $\mu \mathrm{OR}$ activation in the LC have not been established, however, nor has their relation to afferent pathways been examined in this region.

To determine potential sites of $\mu \mathrm{OR}$ activation, we have examined the ultrastructural immunocytochemical localization of $\mu \mathrm{OR}$ immunoreactivity (Surratt et al., 1994). Dual immunocytochemical labeling was conducted in the same section of tissue to determine to what extent LC expression of the $\mu \mathrm{OR}$ is localized to catecholaminergic neurons and to what extent it is localized presynaptically to afferent terminals. These results provide the first ultrastuctural demonstration that the $\mu \mathrm{OR}$ is extensively localized to extrasynaptic sites along the plasma membrane of catecholaminergic dendrites in the LC.

\section{MATERIALS AND METHODS}

Tissue preparation. Four adult male Sprague-Dawley rats (Taconic Farms, NJ), each weighing 200-250 gm, were used in this study. The 


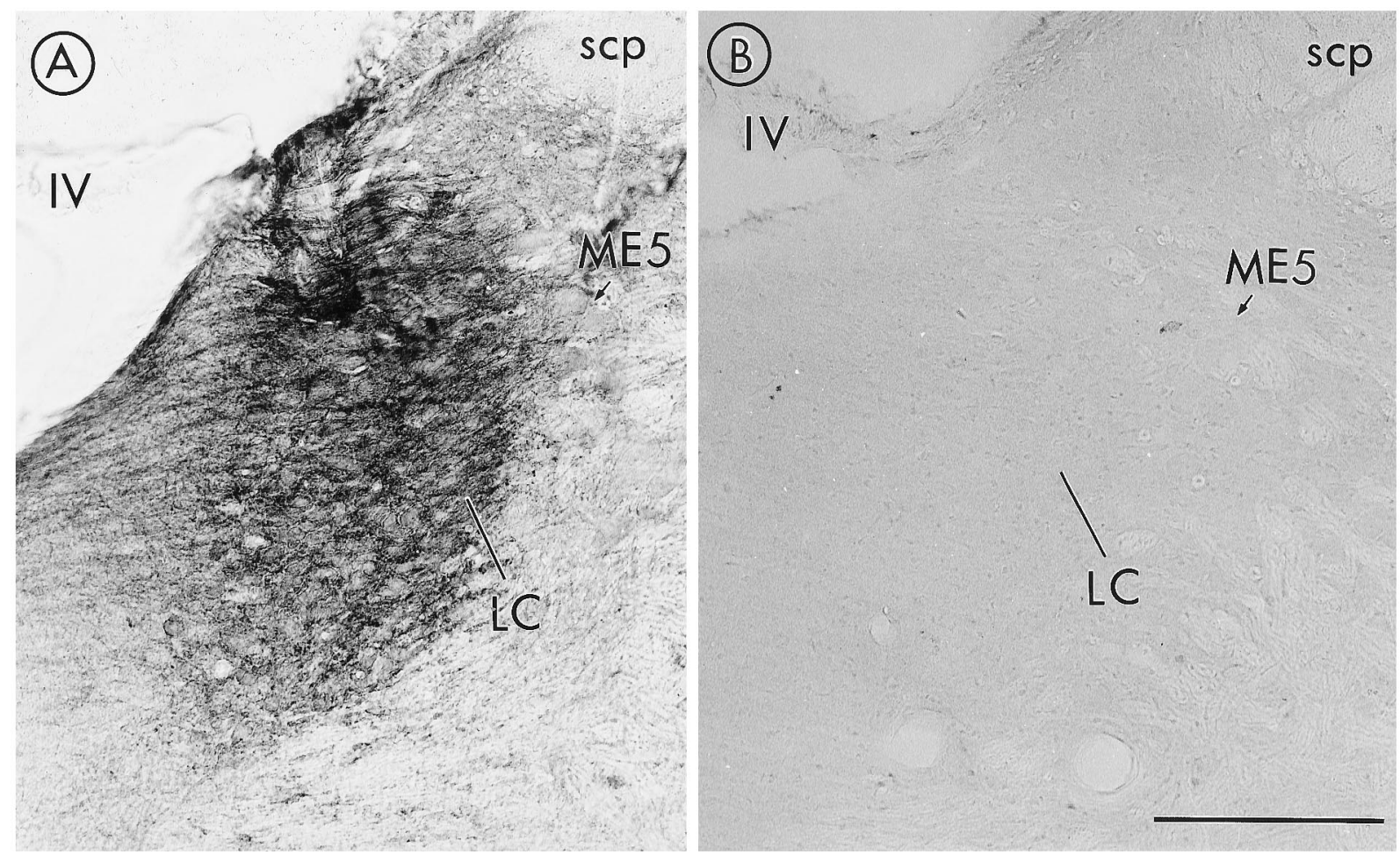

Figure 1. Light microscopic photomicrographs showing preadsorption of the $\mu \mathrm{OR}$ antibody on sections through the locus coeruleus $(L C)$. $A$, Immunoperoxidase labeling of $\mu \mathrm{OR}$ is dense in the LC immediately lateral to the fourth ventricle $(I V)$ and medial to the mesencephalic nucleus of the trigeminal nerve (ME5). Note the distribution of peroxidase immunoreactivity for $\mu \mathrm{OR}$ in cell bodies and dendrites of the LC and the lack of immunolabeling in the superior cerebellar peduncle $(s c p) . B$, A section adjacent to the one shown in $A$ after preadsorption of the antiserum with $10 \mu \mathrm{g} / \mathrm{ml}$ of the cognate peptide. Note that the tissue section is void of peroxidase labeling. Scale bar (shown in $B$ ): $250 \mu \mathrm{m}$.

animals were anesthetized deeply with sodium pentobarbital and perfused transcardially through the ascending aorta with $50 \mathrm{ml}$ of $3.8 \%$ acrolein and $200 \mathrm{ml}$ of $2 \%$ paraformaldehyde in $0.1 \mathrm{M}$ phosphate buffer (PB), pH 7.4. Immediately after perfusion-fixation, the brains were removed, cut into 1-3 mm in thickness coronal slices, and placed in the same fixative for an additional $30 \mathrm{~min}$. Forty-micrometer-thick sections were cut through the rostrocaudal extent of the LC using a Vibratome and collected into $0.1 \mathrm{M} \mathrm{PB}$.

Antisera specificity. The characterization and specificity of the rabbit antiserum against the $\mu \mathrm{OR}$ and the mouse antibody against $\mathrm{TH}$ have been described previously (Van Bockstaele and Pickel, 1993; Surratt et al., 1994). The rabbit polyclonal $\mu \mathrm{OR}$ antiserum was raised against a glutaraldehyde conjugate of the C-terminal 18 amino acids of the rat $\mu \mathrm{OR}$ and keyhole limpet hemocyanin and specifically recognizes immunocytochemical labeling for $\mu \mathrm{OR}$ in Western blots, immunoprecipitation, and light microscopic immunohistochemical studies of native $\mu \mathrm{OR}$ and $\mu \mathrm{OR}$ expressed in cultured cells (Surratt et al., 1994). Immunolabeling was selectively adsorbed with the appropriate peptide (Fig. 1), with concentrations of 1 and $10 \mu \mathrm{g} / \mathrm{ml}$ (also see Cheng et al., in press). Immunodot-blot analysis (Cheng et al., in press) was used to show specificity of the rabbit antiserum against the $\mu$ OR peptide. To evaluate the possible recognition of the primary rabbit antiserum by secondaries against mouse IgGs in the dual-labeling experiments, some sections were processed for dual labeling with omission of the mouse antiserum.

Immunocytochemical labeling. The Vibratome sections were placed for $30 \mathrm{~min}$ in $1 \%$ sodium borohydride in $0.1 \mathrm{M} \mathrm{PB}$ to remove reactive aldehydes (Leranth and Pickel, 1989). Sections were then rinsed extensively in $0.1 \mathrm{M}$ Tris buffered saline (TBS) and incubated for $30 \mathrm{~min}$ in $0.5 \%$ bovine serum albumin (BSA) in $0.1 \mathrm{M}$ TBS for $30 \mathrm{~min}$ before the primary antibody incubation. Tissue sections containing the LC were incubated in a cocktail of rabbit anti- $\mu$ OR antibody (1:20,000 for peroxidase and 1:10,000 for immunogold-silver; Surratt et al., 1993) and a mouse monoclonal anti-TH antibody (1:1000; Incstar). Sections were treated with $0.3 \%$ Triton X-100 for light microscopy but lacked Triton $\mathrm{X}-100$ for electron microscopy.

Methods for dual immunocytochemical labeling have been described previously (Chan et al., 1990; Van Bockstaele et al., 1994). Two methods were used to visualize the antisera. In one set of tissue sections, the $\mu \mathrm{OR}$ was immunolabeled using the immunoperoxidase method, and TH was identified using immunogold silver. In another set, the secondary antisera were reversed such that the $\mu \mathrm{OR}$ was localized using the immunogold silver and TH was localized using the immunoperoxidase method. For both sets, tissue sections were incubated in the primary antibody for $15-18 \mathrm{hr}$ at room temperature. They were then rinsed three times in 0.1 $\mathrm{M}$ TBS and incubated at room temperature for $30 \mathrm{~min}$ either in biotinylated goat anti-rabbit (1:400, Vector Labs, Burlingame, CA) for immunoperoxidase labeling of the $\mu \mathrm{OR}$ or in horse anti-mouse (Vector Labs) for immunoperoxidase labeling of $\mathrm{TH}$.

For peroxidase labeling of $\mathrm{TH}$, sections were then incubated in avidinbiotin complex for $30 \mathrm{~min}$ (Vector Labs) (Hsu et al., 1981). For all incubations and washes, sections were agitated continuously using a Thomas rotator. TH was then visualized by a 4 min reaction in $22 \mathrm{mg}$ of 3-3' diaminobenzidine (Aldrich, Milwaukee, WI) and $10 \mu \mathrm{l}$ of $30 \%$ hydrogen peroxide in $100 \mathrm{ml}$ of $0.1 \mathrm{M}$ TBS. For $\mu \mathrm{OR}$ immunocytochemistry, these sections were subsequently rinsed in $0.01 \mathrm{M}$ PBS and incubated in a solution of $0.01 \mathrm{~m}$ PBS containing $0.1 \%$ gelatin and $0.8 \%$ BSA for $30 \mathrm{~min}$. Sections were then incubated in a goat anti-rabbit IgG conjugated to $1 \mathrm{~nm}$ gold particles (Amersham, Arlington Heights, IL) for $2 \mathrm{hr}$ at room temperature. These were rinsed in $0.01 \mathrm{M}$ PBS containing the same concentrations of gelatin and BSA described above and subsequently rinsed with $0.01 \mathrm{M}$ PBS. Sections were then incubated in $1.25 \%$ glutaraldehyde in $0.01 \mathrm{M}$ PBS for $10 \mathrm{~min}$ followed by a wash in $0.01 \mathrm{M}$ PBS and then in $0.2 \mathrm{M}$ sodium citrate buffer, $\mathrm{pH}$ 7.4. Silver intensification of the gold particles was achieved using a silver enhancement kit (Amersham). The optimal silver enhancement times were determined empirically for each experiment and ranged from 7 to $8 \mathrm{~min}$ for electron microscopy and 11 to 12 min for light microscopy (Chan et al., 1990).

For light microscopy, sections were rinsed in $0.01 \mathrm{M} \mathrm{PB}$, mounted onto gelatin-coated glass slides, air-dried, and coverslipped in DPX (Aldrich). For electron microscopy, sections were rinsed in $0.1 \mathrm{M}$ PBS and incubated in $2 \%$ osmium tetroxide in $0.1 \mathrm{M} \mathrm{PB}$ for $1 \mathrm{hr}$, washed in $0.1 \mathrm{M} \mathrm{PB}$, dehydrated, and flat-embedded in Epon 812 (Leranth and Pickel, 1989). Thin sections of $\sim 55-65 \mathrm{~nm}$ were cut from the outer surface of the tissue with a diamond knife (Diatome, Fort Washington, PA) using an LKB 
ultramicrotome. These were collected on grids and counterstained with uranyl acetate and Reynolds lead citrate.

Data analysis. Thin sections of tissue prepared for electron microscopy were selected immediately adjacent to the fourth ventricle in the region of TH-labeled dendrites corresponding to Plate 50 of the rat brain atlas of Swanson (1992). Analysis was performed on thin sections collected sufficiently close to the outer surface of the tissue to permit detection of both $\mu \mathrm{OR}$ and TH immunoreactivities. The classification of identified cellular elements was based on Peters et al. (1991). Structures were defined as being proximal dendrites if they contained endoplasmic reticulum and were $>0.7$ $\mu \mathrm{m}$ in diameter. Axon terminals were distinguished from unmyelinated axons based on their content of synaptic vesicles and diameter $>0.1 \mu \mathrm{m}$. A terminal was considered to be synaptic when it showed a junctional complex, a restricted zone of parallel membrane apposition with slight enlargement of the intercellular space, and/or associated postsynaptic thickening. Asymmetric synapses were identified by the presence of thick postsynaptic densities (Gray's Type I; Gray, 1959); symmetric synapses, on the other hand, had thin densities (Gray's Type II; Gray, 1959) both pre- and postsynaptically. Nonsynaptic contacts, or appositions, were defined by closely spaced parallel plasma membranes of immunoreactive axons and other axon terminals or dendrites. These lacked recognizable specializations and were not separated by glial processes.

Tissues from animals with the best immunocytochemical labeling and preservation of ultrastructural morphology were included in the analysis. At least 10 grids containing 5-10 thin sections each were collected from the surface of three or more plastic-embedded sections containing the LC from each animal. Photographs were taken only when both the immunoperoxidase reaction product and the immunogold-silver deposits were clearly visible in the same thin sections analyzed. This was done so that results obtained from the quantification of the data were not thwarted by uneven penetration of antisera.

\section{RESULTS}

By light microscopy, $\mu \mathrm{OR}$ was prominently localized to neurons throughout the LC (Fig. $2 A-C$ ) using either immunoperoxidase or immunogold-silver labeling methods. At higher magnification, the peroxidase reaction product for the $\mu \mathrm{OR}$ showed a punctate distribution within LC perikarya and dendrites (Fig. $2 B$ ) with no immunocytochemical labeling apparent in their nuclei (Fig. $2 B$ ). In dually labeled sections of tissue, the intensity of immunolabeling for $\mathrm{TH}$ almost completely obscured the light microscopic detection of $\mu \mathrm{OR}$ in the compact region of the LC, regardless of which markers were used. In the rostral pole of the LC, however, the more sparse distribution of catecholaminergic neurons facilitated the detection of dually labeled neurons (Fig. 2D). At this rostral level, using a peroxidase marker for $\mathrm{TH}$ and gold-silver for $\mu \mathrm{OR}$, high magnification light microscopy enabled a clearer differentiation of both labels. Gold-silver immunolabeling for $\mu \mathrm{OR}$ often seemed to circumscribe somata and dendrites containing peroxidase reaction product for TH (Fig. 2D).

\section{LC $\mathrm{i}-\mu \mathrm{OR}$ is localized primarily to catecholaminergic dendrites and perikarya}

By electron microscopy, TH-immunoreactivity was identified in perikarya, dendrites, and axon terminals, whereas $\mu \mathrm{OR}$ labeling was localized to perikarya and dendrites (Figs. 3, 4, 7, 8) and sometimes to unmyelinated axons and glial processes in the LC (see Fig. 8). A similar pattern of labeling was seen when either peroxidase or gold-silver labels for $\mu \mathrm{OR}$ were used; however, plasmalemmal distributions were seen most clearly when the immunogold-silver method was used. Gold-silver labeling for $\mu \mathrm{OR}$ which was not associated with cellular membranes, judged spurious, was negligible. Therefore, profiles containing as little as one gold-silver particle were classified as immunolabeled.

Dendrites constituted $80 \%(n=200)$, perikarya constituted $10 \%(n=25)$, and axons and glia constituted 10\% $(n=25)$ of the total population of $\mu$ OR-labeled neuronal profiles examined $(n=$ $250)$. Numerous dendrites containing $\mu \mathrm{OR}$ were also dually la- beled for TH. Of the dendrites containing i- $\mu \mathrm{OR}(n=200), 49 \%$ $(n=98)$ also contained immunolabeling for the catecholaminesynthesizing enzyme $\mathrm{TH}$.

Gold-silver labeling for $\mu \mathrm{OR}$ was preferentially associated with the cytoplasmic surfaces of plasma membranes of dendrites and perikarya (Figs. 3, 4, 5). The gold-silver particles were localized extensively along parasynaptic (Fig. $3 A$ ) as well as extrasynaptic (Figs. $3 B, 4$ ) portions of the dendritic membranes. Parasynaptic labeling was defined by the presence of gold-silver particles located along portions of the plasma membrane a short distance from the active zone (Fig. $3 A$ ), whereas extrasynaptic labeling consisted of gold-silver deposits along any portion of the plasma membrane of dendrites (Figs. $3 B, 4 A, B$ ) or perikarya (Figs. 7, 8) in which synaptic input was not seen within the sections examined. Dendrites and perikarya containing $\mathrm{i}-\mu \mathrm{OR}$ along parasynaptic portions of their plasma membranes were often apposed by astrocytic processes that usually lacked $\mu$ OR-labeling (Figs. 4, 5, 7, $8)$. Occasionally, gold-silver particles were associated even more closely with the active zone (Fig. 8) of perikarya or dendrites receiving synaptic contacts from unlabeled terminals; however, these were still usually located somewhat lateral to the postsynaptic specialization. Some gold-silver particles were also occasionally distributed within the cytoplasm of dendrites and perikarya. These were usually seen near saccules of smooth endoplasmic reticulum (Fig. 8).

Peroxidase labeling of $\mu \mathrm{OR}$ yielded a more diffuse pattern of immunoreactivity (Fig. 6) than that observed with the immunogold-silver method. Although denser peroxidase reaction product appeared along portions of the plasma membranes (Fig. 6), some peroxidase labeling could also be identified within cytoplasmic compartments of perikarya and dendrites.

\section{i- $\mu$ OR is localized to dendrites receiving asymmetric synaptic contacts}

Unlabeled axon terminals were often directly apposed to perikarya and dendrites containing i- $\mu \mathrm{OR}$ (Figs. 3, 5-8). Of the dendrites containing i- $\mu \mathrm{OR}(n=200), 81 \%(n=162)$ were apposed by unlabeled axon terminals. Of these axon terminals $(n=162), 45 \%$ $(n=73)$ formed asymmetric-type synaptic contacts. These axon terminals contained abundant small (30-40 nm) clear spherical vesicles (Figs. 3, 4, 6), which were either aggregated near the region of synaptic contact or distributed throughout the axoplasm (Figs. $3 A, B, 4 A, 6 A, B)$. They also frequently contained at least one but sometimes as many as seven or more large dense-core vesicles (Figs. $3,6)$. The dense-core vesicles were located primarily along the perimeter of the axonal membrane distal to the synaptic contact with dendrites (Figs. $3 A, 6 A$ ). More commonly, the dense-core vesicles were located near portions of the axonal plasmalemma near astrocytic processes (Figs. $3 A, 6 A$ ). The astrocytic processes often directly intervened between neighboring TH-labeled (Fig. 6A,B) or unlabeled dendrites (Fig. $4 B$ ). In contrast, of the axon terminals in synaptic contact with $\mu$ OR-labeled dendrites $(n=162)$, only $15 \%$ ( $n=24$ ) formed symmetric-type synapses (not shown). The remaining axon terminals $(n=65)$ apposed to the $\mu$ OR-labeled dendrites could not be classified into either category (i.e., asymmetric vs symmetric), because the synaptic specialization was not evident in the plane of section analyzed.

The $\mu$ OR-labeled recipient dendrites were medium in size and ranged from 0.5 to $2.0 \mu \mathrm{m}$ in cross-sectional diameter (mean: $0.7 \pm 0.2 \mu \mathrm{m})$. Other smaller processes $(<0.3 \mu \mathrm{m}$ in crosssectional diameter) also contained $\mathrm{i}-\mu \mathrm{OR}$ immunoreactivity. 

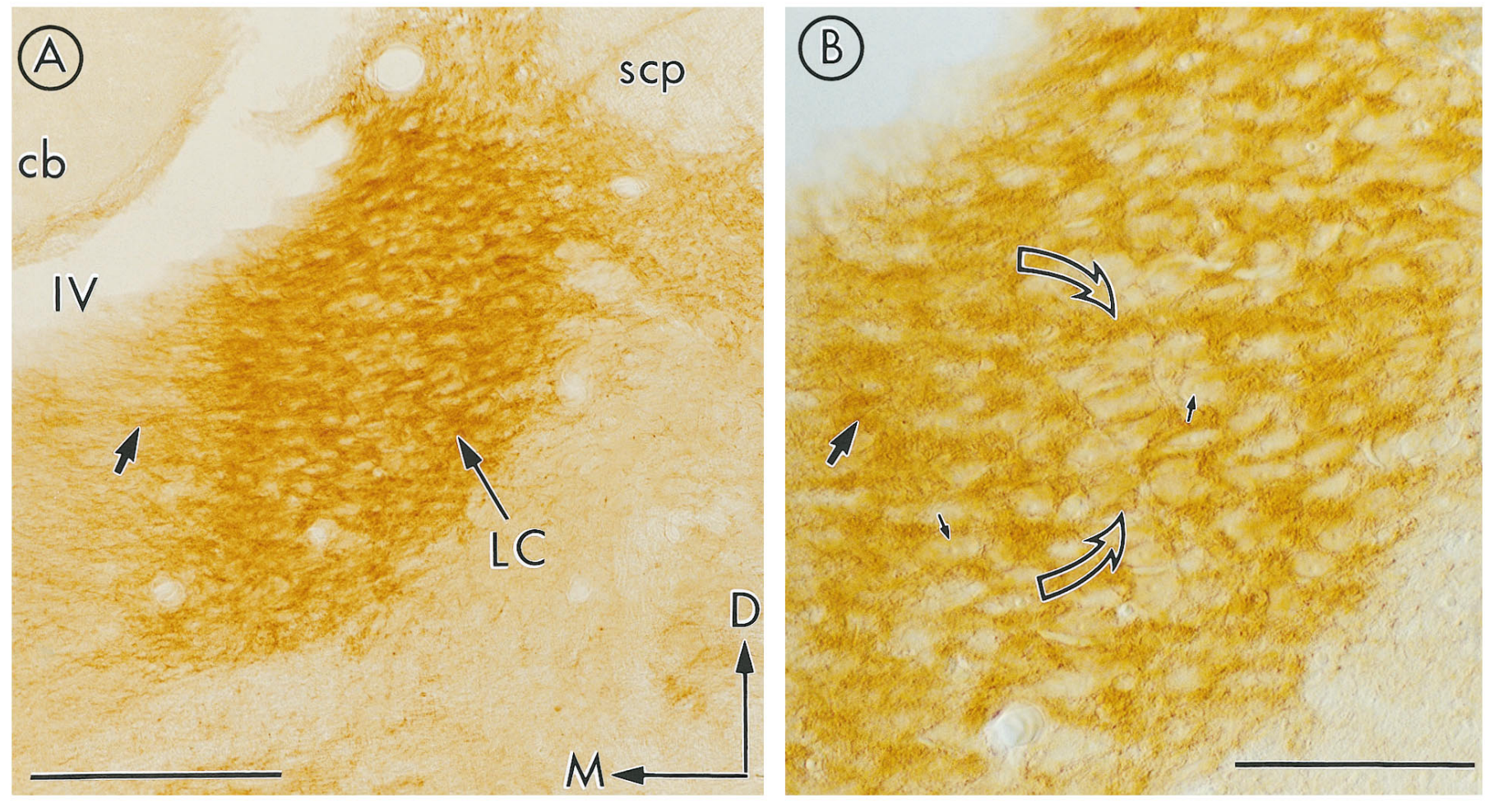

\section{(C)}

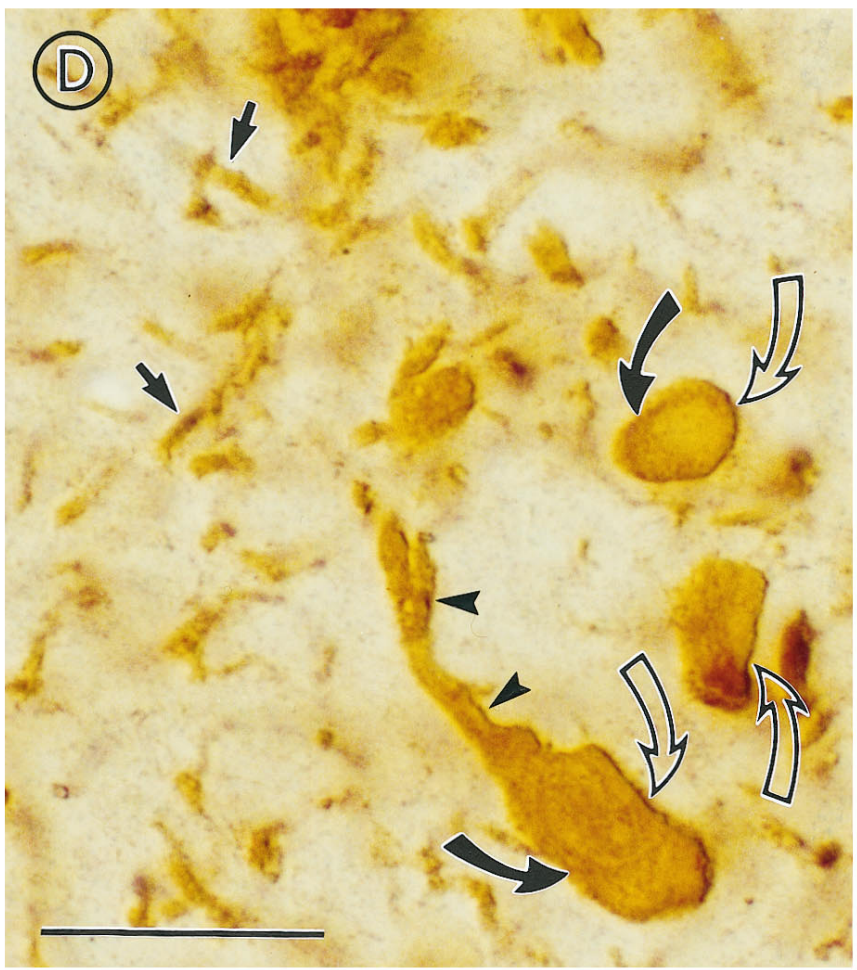

Figure 2. Light microscopy showing the cellular localization of the $\mu \mathrm{OR}$ and its relation to $\mathrm{TH}$ in the nucleus locus coeruleus $(L C)$. $A$, In the dorsal pons at the level of Plate 52 in the rat brain atlas of Swanson (1992), dense peroxidase reaction product for $\mu$ OR is seen immediately adjacent to the fourth ventricle $(I V)$. Immunolabeled processes extend medially (straight black arrow) in a zone known to contain dendrites of the noradrenergic neurons of the LC. $c b$, Cerebellum; $s c p$, superior cerebellar peduncle. Arrows point dorsally $(D)$ and medially $(M)$. $B$, A higher-magnification photomicrograph from the same level as in $A$ showing $\mu \mathrm{OR}$ immunoreactivity (curved arrows) near the perimeter of perikarya, the cytoplasm and nuclei of which are unlabeled (small black arrows). The larger straight black arrow points to the medial aspect of the LC, which contains extensive noradrenergic dendrites. $C$, $\mu \mathrm{OR}$ immunoreactivity in the rostral pole of the LC rims the plasma membrane of a compact group of unlabeled perikarya. A punctate staining pattern (curved arrow) is seen within a region of the LC known to contain extensive noradrenergic dendrites (straight black arrows). In $D$, $\mathrm{i}-\mu \mathrm{OR}$ labeling (open curved arrows) appears as a dark halo along the perimeter of TH-labeled cell bodies (closed curved arrows) and dendrites (straight black arrows). One TH-labeled cell with a long proximal dendrite (small black arrowheads) contains $\mu$ OR labeling along its plasma membrane. Scale bars: $A, 250 \mu \mathrm{m} ; B, 100 \mu \mathrm{m} ; C, 225$ $\mu \mathrm{m} ; D, 20 \mu \mathrm{m}$. 

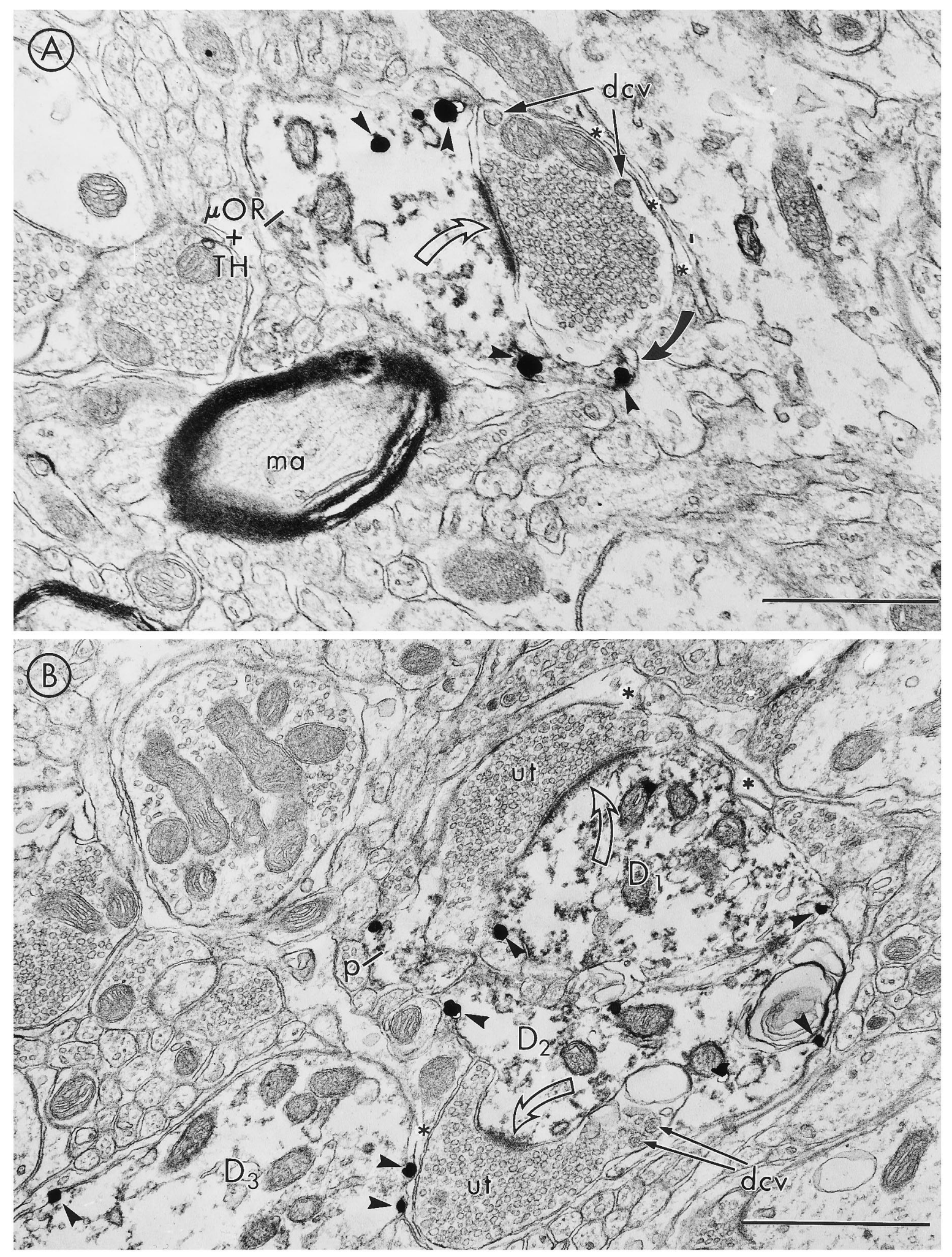

Figure 3. Unlabeled terminals form asymmetric (excitatory-type) synaptic junctions with dendrites containing peroxidase reaction product (black diffuse precipitate) for tyrosine hydroxylase $(T H)$ and immunogold-silver (large dense particles at arrowheads) for the $\mu$-opioid receptor ( $\mu O R$ ). $A$, A small dendrite containing $\mu O R+T H$ immunoreactivities receives an asymmetric-type synapse (open curved arrow) from an unlabeled terminal. The unlabeled terminal contains numerous small clear vesicles and a few large dense-core vesicles $(d c v)$ and is apposed to an astrocytic process (asterisks). The unlabeled terminal is partially enveloped (black curved arrow) by an extension of the dendritic plasma membrane showing the presence of two gold-silver deposits (black arrowheads) for $\mu \mathrm{OR}$. ma, Myelinated axon. $B$, Two unlabeled terminals $(u t)$ containing small clear and large dcvs form asymmetric synapses (open curved arrows) with two TH-labeled dendrites $\left(D_{1}\right.$ and $\left.D_{2}\right)$. A small dually labeled process $(p)$ lies adjacent to the $D_{2}$ and the dorsal ut. Another TH-labeled dendrite $\left(D_{3}\right)$ contains gold-silver deposits for $\mu \mathrm{OR}$ along its plasma membrane adjacent to the more ventral $u t$. Scale bar for $A$, $0.4 \mu \mathrm{m}$. Asterisks denote astrocytic processes. Scale bar for $B, 0.5 \mu \mathrm{m}$. 


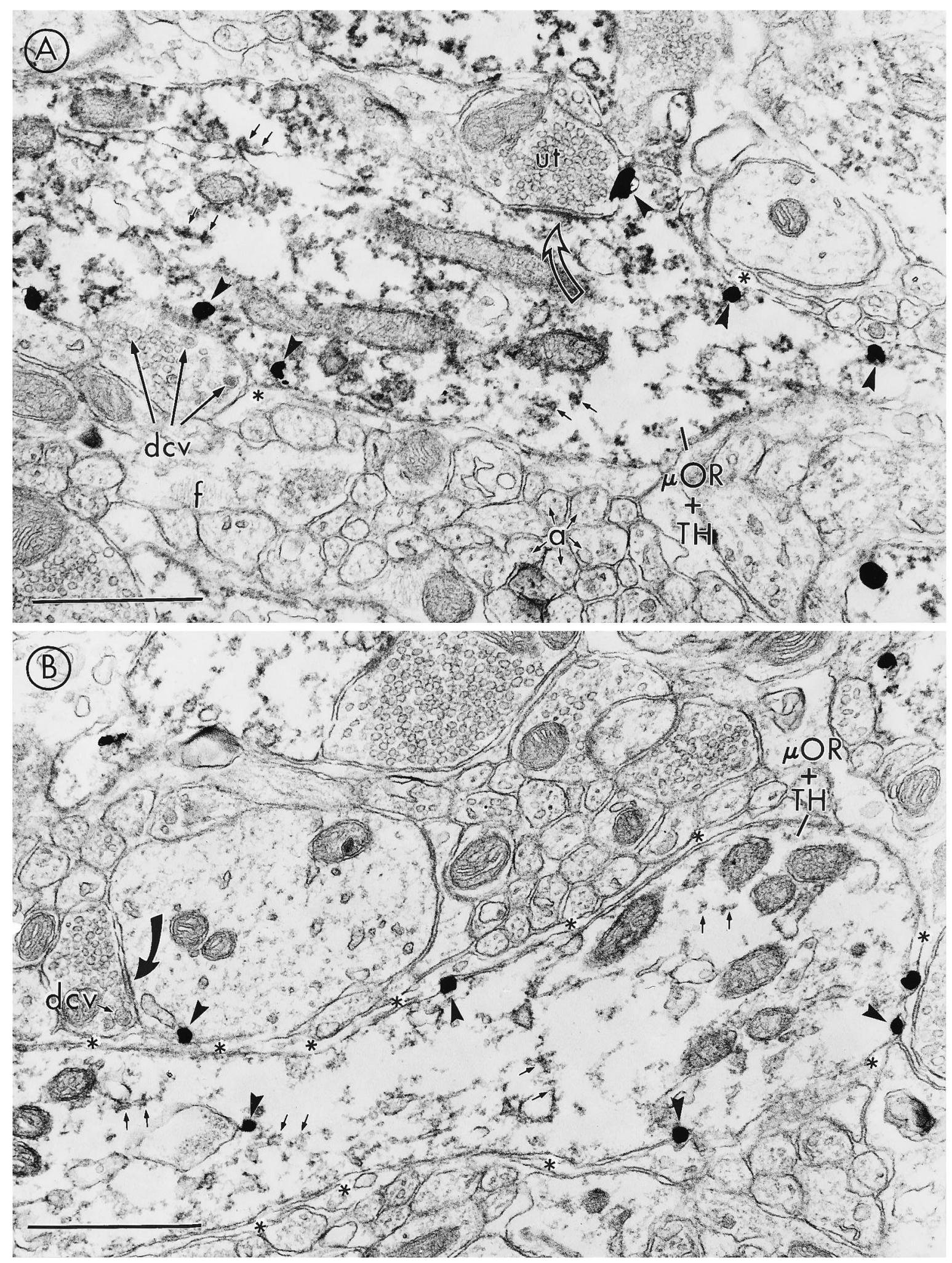

Figure 4. Plasmalemmal distribution of immunogold-silver labeling for $\mu$-opioid receptor $(\mu O R)$ in dendrites containing peroxidase reaction product for tyrosine hydroxylase $(T H)$ in the nucleus locus coeruleus. $A, B$, Two longitudinally sectioned dendrites contain peroxidase labeling for $T H$ (small black arrows) and possess gold-silver deposits (arrowheads) for i- $\mu$ OR along their plasmalemmal surface. In $A$, an unlabeled terminal (ut) forms a synaptic contact (open curved arrow) with the $\mu O R+T H$-labeled dendrite. Another axon terminal containing numerous dense-core vesicles $(d c v)$ is also apposed to the $\mu \mathrm{OR}+$ TH-labeled dendrite. An astrocyte containing filamentous $(f)$ processes and bundles of unmyelinated axons $(a)$ can also be identified in the neuropil. In $B, a \mu \mathrm{OR}+\mathrm{TH}$-labeled dendrite is enveloped by an astrocytic process (asterisks) and receives no synaptic contacts in this plane of section. A dendrite containing one gold-silver particle (arrowhead) along its plasma membrane is located immediately adjacent to the $\mu \mathrm{OR}+\mathrm{TH}$ dendrite but is largely separated from it by an astrocytic process (asterisks). This dendrite receives a synaptic contact (curved black arrow) from an unlabeled terminal containing a $d c v$. This dendrite lacks the diffuse cytoplasmic labeling indicative of peroxidase reaction product for TH. Scale bars: $A, 0.4 \mu \mathrm{m} ; B, 0.5 \mu \mathrm{m}$. 


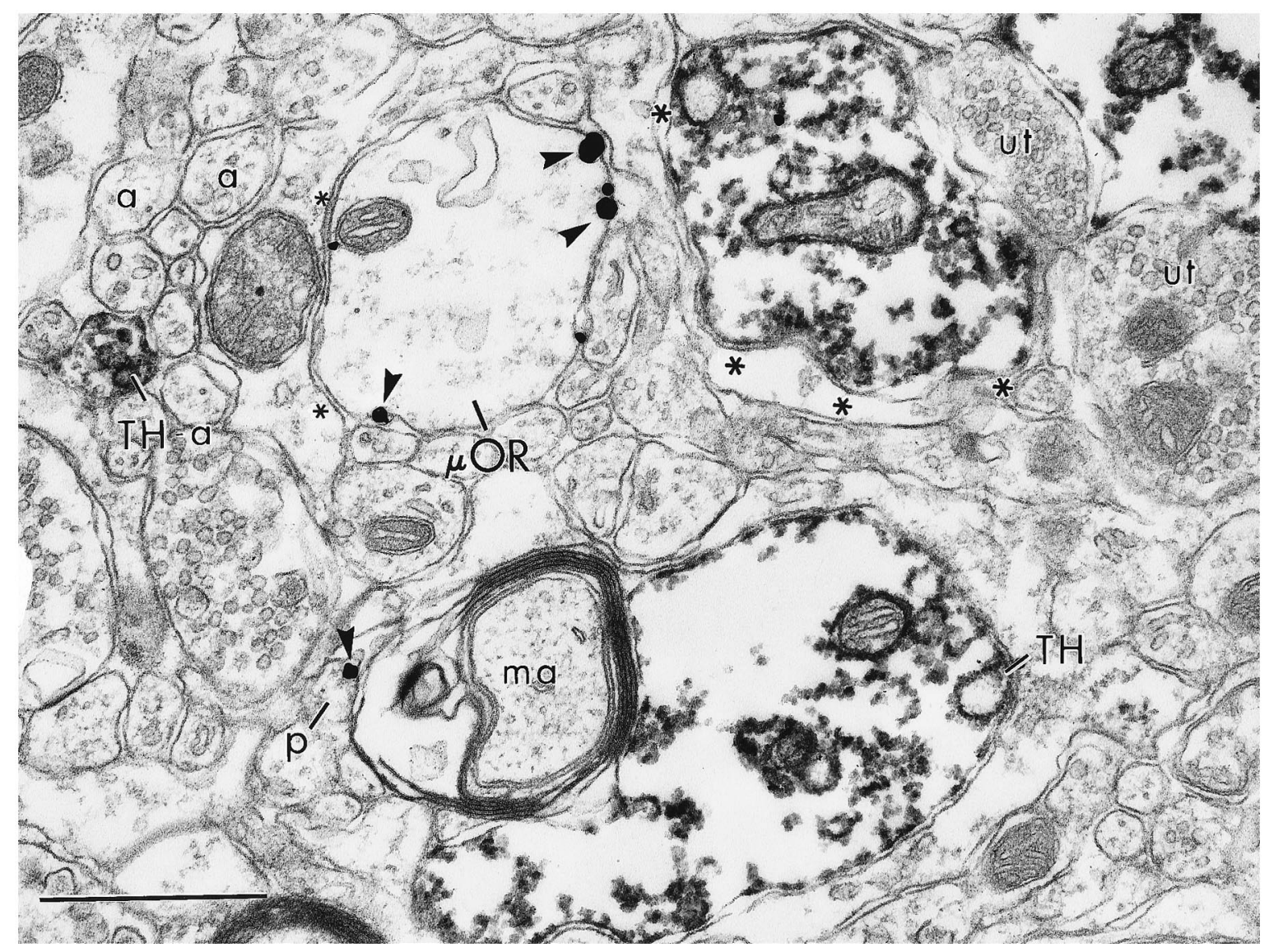

Figure 5. In the rostral pole of the LC, dendrites differentially express gold-silver labeling for the $\mu$-opioid receptor $(\mu O R)$ and immunoperoxidase labeling for TH. One TH-labeled dendrite $(T H)$ is apposed to a myelinated axon $(m a)$. A similarly TH-labeled dendrite in the upper right of the micrograph is located near unlabeled terminals $(u t)$ but appears largely separated from the neuropil by a glial process (asterisks). A nearby dendrite shows gold-silver labeling (arrowheads) for $\mu \mathrm{OR}$ along the plasma membrane but does not contain TH immunoreactivity. A TH-labeled axon (TH- $a$ ) can be identified among other unlabeled axons $(a)$. Additionally, a process $(p)$ resembling an unmyelinated axon contains gold-silver labeling for $\mu$ OR. Scale bar, $0.5 \mu \mathrm{m}$.

These usually contained few cytoplasmic organelles and had ultrastructural features characteristic of dendritic spines.

\section{$\mathrm{i}-\mu \mathrm{OR}$ is occasionally localized to unmyelinated axons and axon terminals}

Ten percent of the neuronal profiles containing $\mathrm{i}-\mu \mathrm{OR}$ were unmyelinated axons and glial processes. $\mathrm{i}-\mu \mathrm{OR}$ associated with small unmyelinated axons was observed when either labeling method was used (Figs. 5, 6A). The i- $\mu \mathrm{OR}$ unmyelinated axons were often found within bundles that also contained other unlabeled, unmyelinated axons (Figs. 5, 6A). Some small unmyelinated axons were also in direct contact with larger myelinated axons (Fig. 5). A few $\mu$ OR-labeled neuronal profiles were considered to be axon terminals on the basis of their larger diameters and accumulation of synaptic vesicles (Fig. 7). In $\mu$ OR-labeled axon terminals, isolated gold-silver deposits were associated with the plasma membranes and were also seen near synaptic vesicles (Fig. 7). The $\mu$ OR-labeled axon terminals were apposed to either unlabeled dendrites or unlabeled axon terminals.

\section{$\mathrm{i}-\mu \mathrm{OR}$ is also sometimes found over closely investing glial processes}

Perikarya and dendrites containing i- $\mu \mathrm{OR}$ immunoreactivity were often enveloped by glial processes (Figs. 3-8). Almost $90 \%$ of the profiles containing $\mu \mathrm{OR}$ immunoreactivity were apposed to a glial process along some portion of their plasma membrane. Such processes separated $\mu$ OR-labeled dendrites from other terminals (Fig. $6 B$ ) or from unlabeled or TH-labeled dendrites (Figs. $4 B, 6 B$ ). Furthermore, some glial processes seemed to closely envelop complexes of $\mu$ OR-labeled dendrites and axon terminals that formed synaptic contacts with their postsynaptic targets (Fig. 6), such that the only elements that the unlabeled terminal could contact would be the target dendrite or the glial process. Recognizable astrocytic processes containing bundles of filaments rarely showed immunogold-silver labeling for $\mu \mathrm{OR}$ (Fig. 8). In some cases, however, the plasma membranes of glial processes near or apposed to $\mu$ OR-labeled neurons were also immunolabeled for $\mu \mathrm{OR}$ (Fig. 8).

\section{DISCUSSION}

The results of this study provide the first ultrastructural evidence that $\mu \mathrm{OR}$ immunoreactivity is localized prominently to parasynaptic and extrasynaptic portions of dendritic and somatic plasma membranes of noradrenergic neurons of the LC. The $\mu \mathrm{OR}-$ labeled dendrites were preferentially targeted by axon terminals containing heterogeneous types of synaptic vesicles and forming primarily asymmetric (excitatory-type) synapses. Some i- $\mu$ OR immunoreactivity was also associated with small unmyelinated axons, axon terminals, and possibly glial processes. Finally, we showed a more prominent differential distribution of $\mu \mathrm{OR}$ immu- 

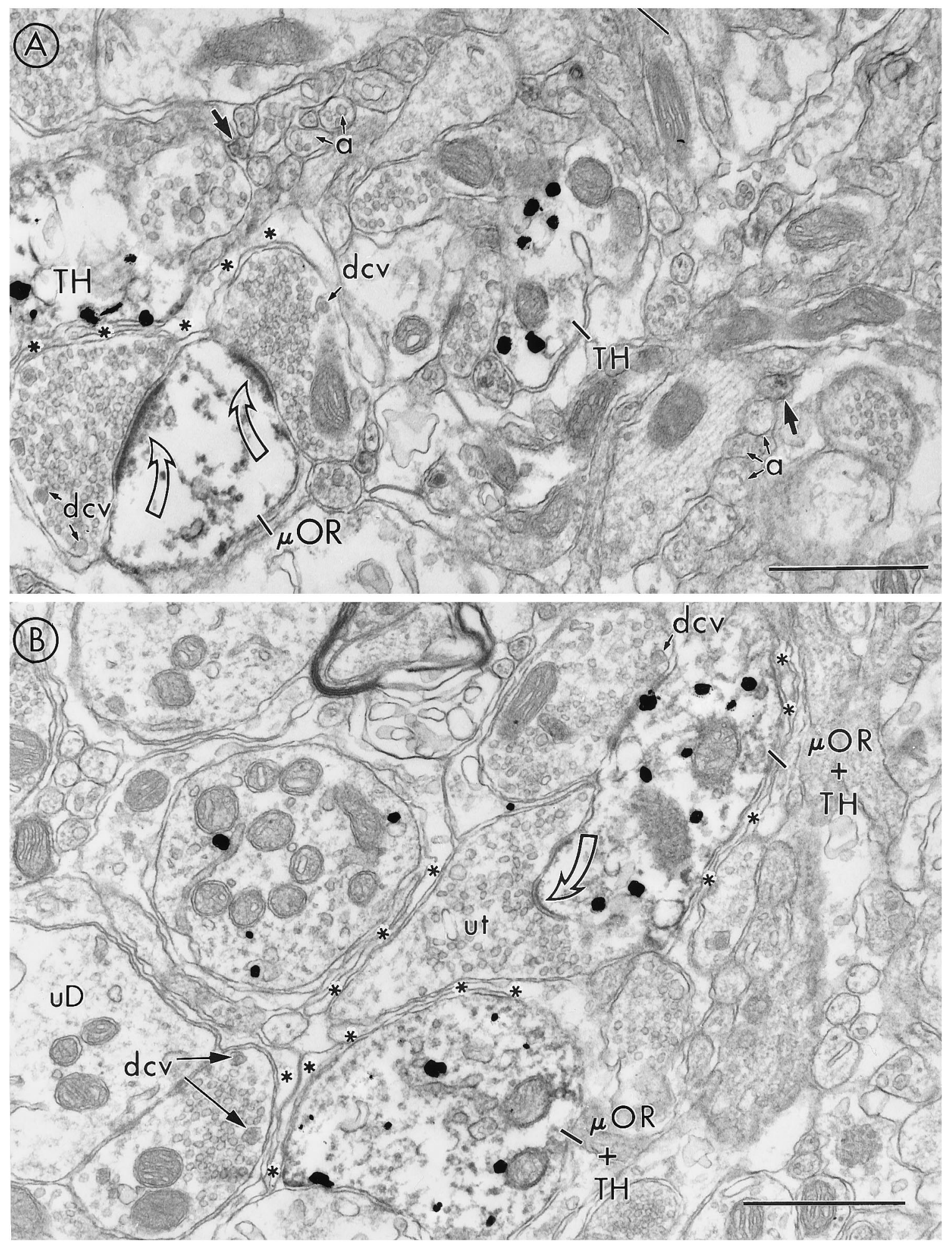

Figure 6. Electron micrographs showing peroxidase labeling for the $\mu$-opiate receptor $(\mu O R)$ in dendrites with and without immunogold-silver labeling for tyrosine hydroxylase $(T H)$. A, Two unlabeled terminals containing dense-core vesicles ( $d c v \mathrm{~s}$ ) form asymmetric synapses (open curved arrows) onto a common $\mu$ OR-labeled dendrite. This dendrite lacks gold-silver labeling for TH, although TH-immunoreactivity is clearly present in the neuropil. The unlabeled terminals containing the $\mathrm{dcv}$ are apposed by astrocytic processes (asterisks). Note bundles of unmyelinated axons ( $a$ ) in the neuropil. In these bundles, occasional axons contain peroxidase labeling for $\mu \mathrm{OR}$ (straight black arrows). $B$, Two dendrites containing peroxidase labeling for $\mu \mathrm{OR}$ also contain gold-silver labeling for TH. An unlabeled terminal (ut), which is enveloped by an astrocytic process (asterisks), forms a synaptic contact (open curved arrow) with a dendrite containing $\mu O R+T H$. The $\mu \mathrm{OR}+\mathrm{TH}$ dendrite also receives convergent input from another $u t$ that contains a $d c v$. The astrocytic process (asterisks) separates the $u t$ from another $\mu \mathrm{OR}+\mathrm{TH}$-labeled dendrite. Note that an unlabeled terminal containing dcvs is directly apposed to an unlabeled dendrite $(u D)$. Throughout the neuropil, $d c v$ s are apposed to portions of the plasma membranes, which are in direct contact with astrocytic processes (asterisks). Scale bars: $A, 0.5 \mu \mathrm{m} ; B, 0.6 \mu \mathrm{m}$. 


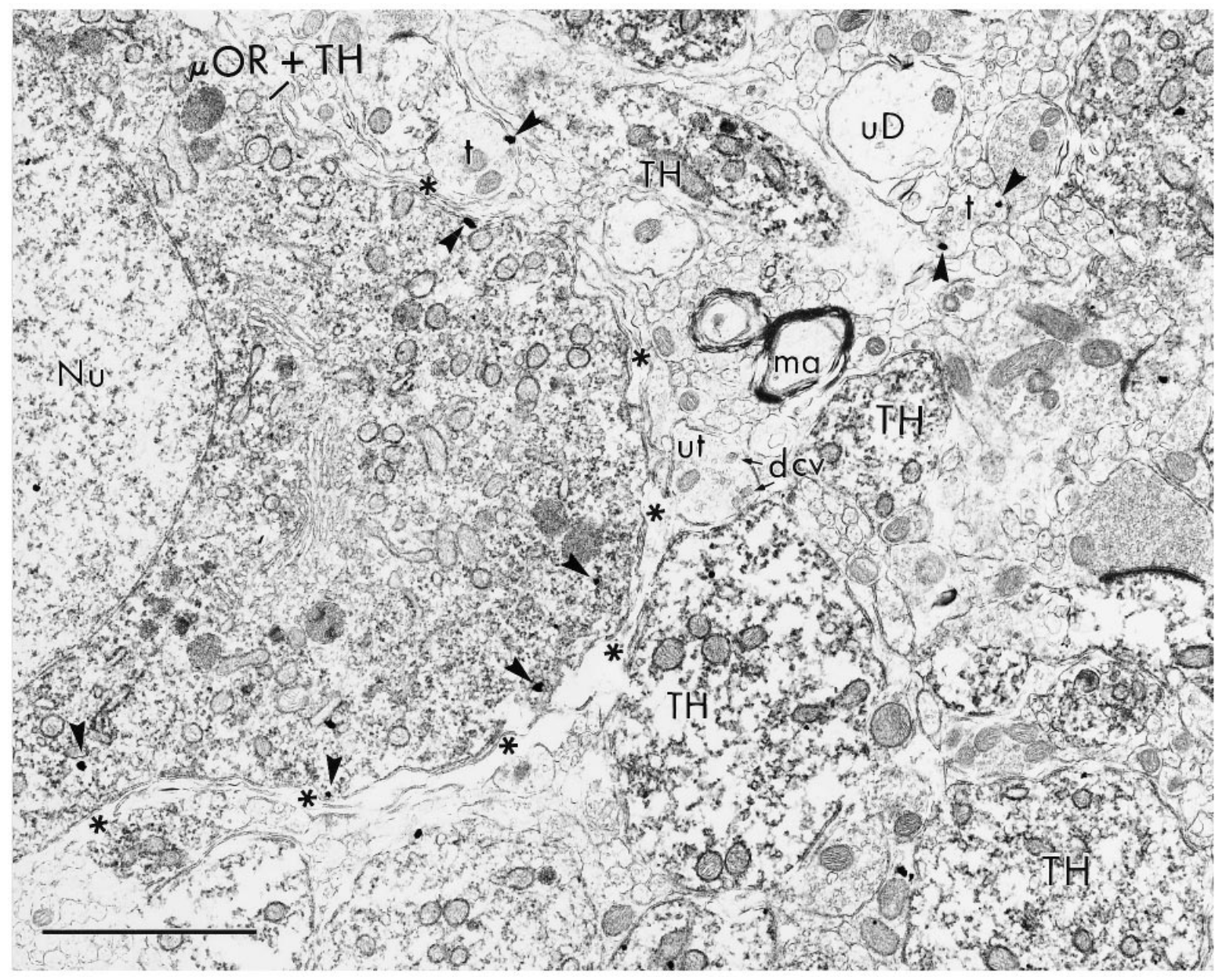

Figure 7. Low-magnification electron micrograph showing peroxidase reaction product for tyrosine hydroxylase $(T H)$ in a soma, defined by the presence of a nucleus $(\mathrm{Nu})$, which contains prominent plasmalemmal immunogold-silver labeling (arrowheads) for the $\mu$-opioid receptor ( $\mu O R$ ). An unlabeled terminal ( $u t)$, which contains several dense-core vesicles $(d c v)$, is separated from the $\mu O R+T H$-labeled dendrite by an astrocytic process $($ asterisks). The astrocytic process envelops the entire soma (asterisks). The neuropil is also enriched with numerous TH-labeled dendrites, most of which have little or no immunogold-silver labeling for $\mu \mathrm{OR}$. An unlabeled dendrite $(u D)$ can be seen in the neuropil in the upper right portion of the micrograph. Some isolated axon terminals $(t)$ contain one or more gold-silver deposits (arrowheads) for $\mu \mathrm{OR}$. Scale bar, $1 \mu \mathrm{m}$.

noreactivity along extrasynaptic portions of dendrites with and without detectable levels of the catecholamine-synthesizing enzyme TH in the rostral pole of the LC.

\section{Methodological considerations}

Previous experiments have shown the characterization of the polyclonal antiserum used in the present study, including Western blotting, immunoprecipitation, and light microscopic immunohistochemical studies (Surratt et al., 1994). Selective, adsorbable immunocytochemical labeling within various brain regions and immunodot-blot preparations performed in our laboratory have shown that the antibody recognizes amino acid sequences within $\mu \mathrm{OR}$, but not sequences of $\delta$ or $\kappa$ receptors (Cheng et al., in press). Most of the reaction product for $\mu \mathrm{OR}$ was localized to the cytoplasmic side of the plasma membranes of perikarya and dendrites, which is consistent with current models in which the $\mu \mathrm{OR} C$-terminus amino acid sequence is thought to be cytoplasmic (Wang et al., 1993). The $\mu \mathrm{OR}$ immunoreactivity was also associated with saccules of smooth endoplasmic reticulum within the cytoplasm (Fig. 8). Such organelles are involved in the intracellular transport of plasma membranes and plasma membrane proteins from the cell somata to dendrites and axon terminals
(Rodriguez-Boulan and Powell, 1992). The monocolonal antiserum against $\mathrm{TH}$ also specifically recognizes the catecholaminesynthesizing enzyme (Van Bockstaele and Pickel, 1993).

The quantitative approach used in the present study has been discussed previously (Van Bockstaele and Pickel, 1993; Van Bockstaele et al., 1994). To ensure the reproducibility of the quantitative evaluation of the types of junctions formed by immunoreactive processes and/or their frequency of association with other labeled or unlabeled cellular constituents, our analysis was restricted to sections collected from the surface of the tissue, which ensured that both markers were detectable in all sections used for analysis (Chan et al., 1990).

The intense distribution of $\mathrm{i}-\mu \mathrm{OR}$ immunoreactivity in the $\mathrm{LC}$ is in agreement with previous studies that used autoradiography to localize $\mu \mathrm{OR}$ ligands in this region (Atweh and Kuhar, 1977; Tempel and Zukin, 1987), as well as studies showing that $\mu \mathrm{OR}$ mRNA is expressed by cells in the LC area (Mansour et al., 1995). The methodology used here, however, complements and extends results from receptor autoradiography (Atweh and Kuhar, 1977; Tempel and Zukin, 1987), because it displays much higher resolution such as determinations of $\mu \mathrm{OR}$ distributions within neurons, astrocytic pro- 


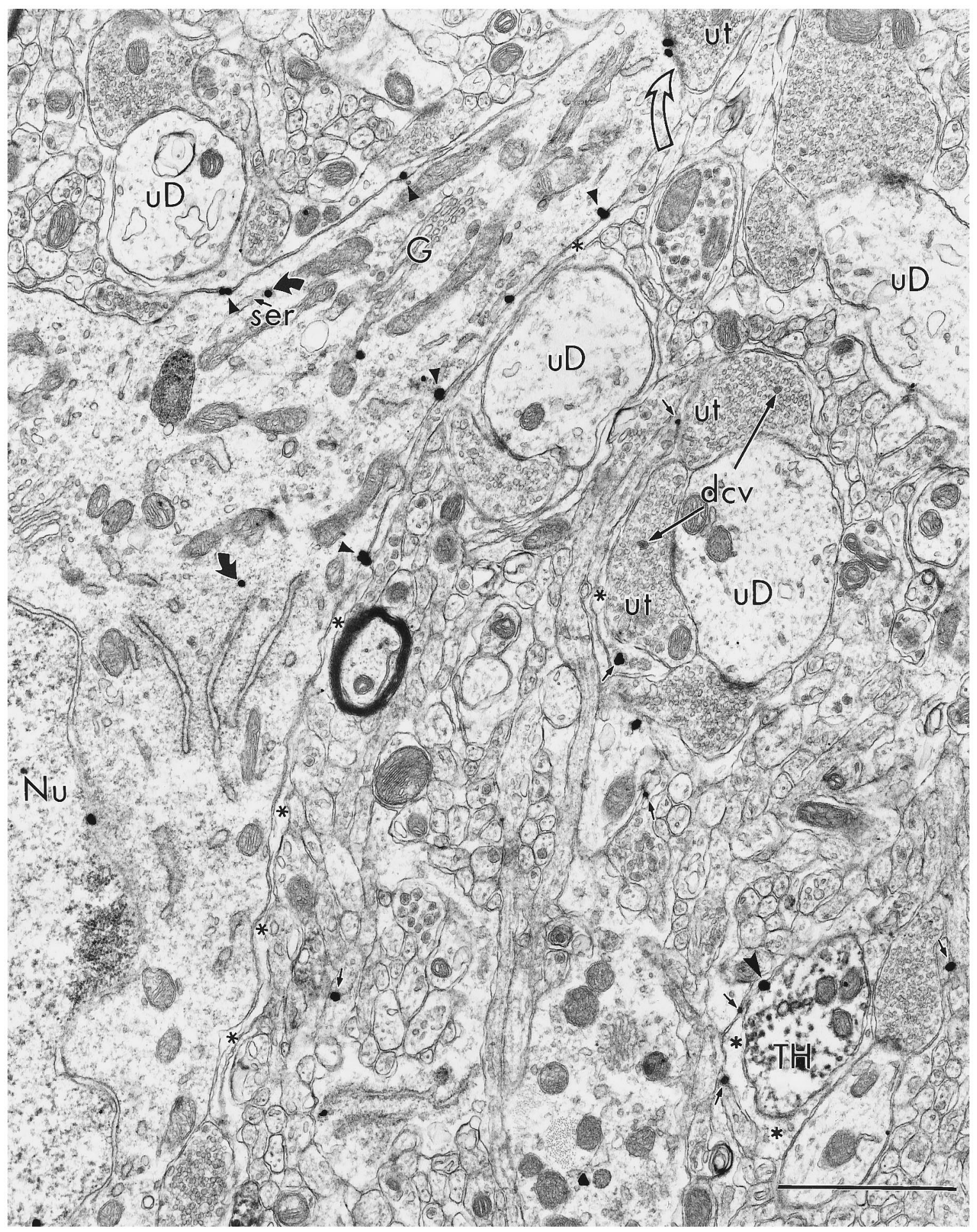

Figure 8. Low-magnification electron micrograph showing peroxidase reaction product for TH and immunogold-silver labeling for $\mu$-opiate receptor $(\mu O R)$ in neuronal and glial profiles in the rostral pole of the LC. Immunoperoxidase labeling for TH can be detected in a dendrite (TH) among numerous unlabeled dendrites $(u D)$ in the neuropil. The TH-labeled dendrite is enveloped by an astrocytic process (asterisks). One $u D$ is directly apposed by unlabeled terminals $(u t)$, two of which contain large dense-core vesicles $(d c v)$. Immunogold-silver labeling for $\mu \mathrm{OR}$ is localized to a soma containing a nucleus $(N)$. The gold-silver labeling for $\mu \mathrm{OR}$ is primarily localized to the plasmalemmal surface of the soma (arrowheads); however, some gold-silver particles (black curved arrows) are also distributed within the cytoplasm. The gold-silver particles in the cytoplasm are sometimes associated with smooth endoplasmic reticulum (ser). At the top of the micrograph, a ut can be seen to form a synaptic contact (open curved arrow) with the $\mu$ OR-labeled soma. Note the location of two gold-silver particles near the site of the synaptic junction. Astrocytic processes (asterisks) envelop the soma along other portions of its plasmalemma. Note numerous gold-silver deposits (small straight arrows) associated with glial processes within the neuropil. Scale bar, $2.0 \mu \mathrm{m}$. 
cesses, or axon terminals, and differential localization of $\mu \mathrm{OR}$ with respect to perikarya and dendrites. These are important issues because immunocytochemical and Golgi examinations have indicated that dendrites from LC neurons ramify extensively outside of the cell body region (Swanson, 1976; Grzanna and Molliver, 1980; AstonJones et al., 1991; Shipley et al., 1996).

\section{Neuronal plasmalemmal localization}

i- $\mu$ OR was identified predominantly along parasynaptic and extrasynaptic portions of the plasma membranes of LC perikarya and their dendrites; about half of the dendrites contained $\mathrm{TH}$. Interestingly, little immunolabeling for $\mu \mathrm{OR}$ was observed at the zone of synaptic contact with the postsynaptic target. Some (Nusser et al., 1995) have suggested that lack of immunoreactivity for receptors at the active zone may be the result of methodological approaches. Nusser et al. (1995) failed to obtain immunolabeling for the GABA-A receptor at the active zone using preembedding immunoelectron microscopy, but they were successful when using postembedding immunoelectron microscopic methods. We believe, however, that the largely parasynaptic and extrasynaptic accumulation of reaction product for $\mathrm{i}-\mu \mathrm{OR}$ in our study most likely represents the functional subcellular distribution of the $\mu \mathrm{OR}$ protein in the LC. First, the observed similarities in immunolabeling obtained with immunogold-silver and peroxidase methodologies and the detection of labeling at parasynaptic and extrasynaptic sites with both methods makes it unlikely that this distribution reflects only incomplete penetration to postsynaptic zones (Nusser et al., 1995). Second, the parasynaptic and extrasynaptic localization of $\mu \mathrm{OR}$ is also supported by our previous observation that large dense-core vesicles containing one of the potential endogenous opioid peptides for $\mu \mathrm{OR}$, methionine ${ }^{5}$ ENK (Van Bockstaele et al., 1994), are rarely clustered at the synaptic specialization but are more often localized to the perimeter of axon terminals. This distribution is analogous to that of the dense-core vesicles in unlabeled axon terminals contacting the $\mathrm{i}-\mu \mathrm{OR}$ dendrites in the present study. This suggests, therefore, that the distribution of receptive sites for opioid peptides may be more complex, because release may occur from dense-core vesicles at extrasynaptic sites (Zhu et al., 1986; Pickel et al., 1995). In some cases, however, when either peroxidase or gold-silver markers were used for localizing $\mu \mathrm{OR}$, some synaptic junctions appeared to be immunolabeled (Figs. $6 A, 8$ ). These immunolabeled synapses were usually associated with unlabeled axon terminals forming asymmetric type contacts.

The presence of $\mu \mathrm{OR}$ in LC perikarya and dendrites and its less frequent distribution in axons and axon terminals suggests that this receptor may function primarily in a postsynaptic manner in LC. Although the mid-LC region displayed a preponderance of perikarya and dendrites that contained both $\mu \mathrm{OR}$ and TH, LC dendrites in the rostral pole frequently contained $\mu \mathrm{OR}$ immunoreactivity but lacked TH labeling. These data suggest that $\mu \mathrm{OR}$ activation may include noncatecholaminergic neurons in this brain region and afferents to this region.

\section{Input from axon terminals containing heterogeneous synaptic vesicles}

Axon terminals in synaptic contact with $\mu \mathrm{OR}$-labeled perikarya and dendrites contained both small clear vesicles and large densecore vesicles and more often formed asymmetric-type specializations, suggesting that they may contain an excitatory transmitter, i.e., glutamate and a neuropeptide (Zhu et al., 1986; Pickel et al., 1995). Such a distribution of synaptic vesicles is characteristic of opioid-containing terminals (Van Bockstaele et al., 1995) in the
LC and has been described in other brain regions, including the area postrema and the nucleus of the solitary tract (Pickel et al., 1979; Armstrong et al., 1981). The potential colocalization of endogenous opioid peptides and glutamate has yet to be established unequivocally in individual axon terminals of the LC but is also suggested by our previous study (Van Bockstaele et al., 1995). $\mu \mathrm{OR}$ agonists (1) inhibit the spontaneous activity of LC neurons (North and Williams, 1985; Aghajanian and Wang, 1986; North et al., 1987), (2) inhibit LC adenylate cyclase activity (Duman et al., 1988; Beitner et al., 1989), and (3) decrease LC cAMP-dependent protein phosphorylation (Guitart and Nestler, 1989, 1993) in neurons of the LC. Our study shows that many of the unlabeled terminals that formed synaptic contacts with $\mu$ OR-labeled dendrites were characteristic of excitatory transmission (Carlin et al., 1980; Valtschanoff et al., 1994). Differential release of the excitatory transmitter and the opioid peptide could potentially explain these discrepancies. Further studies are required to determine whether opioid peptides are colocalized with excitatory transmitters such as glutamate, and if so, whether the afferent terminals differentially release these transmitters.

The location of the dense-core vesicles along the perimeter of the plasma membranes of axon terminals is interesting in light of potential sites of transmitter release. Our localization of $i-\mu \mathrm{OR}$ to primarily parasynaptic and extrasynaptic portions of the plasmalemma of perikarya and dendrites of LC neurons suggests that the endogenous peptide may be released from sites distal to the zone of synaptic junction, as suggested for other brain regions (Cheng et al., in press; Svingos et al., in press). Release from extrasynaptic portions of the plasma membrane rather than at the active zone (Zhu et al., 1986) may be characteristic of peptides. Astrocytic processes were commonly found apposed to portions of the plasmalemma in contact with dense-core vesicles. It is conceivable that glial processes may serve to facilitate diffusion of the transmitter into the neuropil to receptive sites on extrasynaptic portions of the postsynaptic cell (Pickel et al., 1995). It has been shown in other brain regions that astrocytes can produce enkephalin (Schwartz et al., 1994). In the noradrenergic neurons of the nucleus of the solitary tract, $\beta$-adrenergic receptors are localized to astrocytes that surround TH-immunoreactive neurons (Aoki and Pickel, 1992). Moreover, $\beta$-adrenergic receptors stimulate the production of preproenkephalin in astrocytic cultures (Schwartz et al., 1994). This evidence suggests a potentially novel form of communication in which noradrenergic release from dendrites or afferents to the LC may stimulate the production of enkephalin peptides that are released to activate the $\mu$-opioid receptive sites on perikarya and dendrites of the LC. Furthermore, $\mu \mathrm{OR}$ receptive sites on astrocytic processes may indirectly affect the activity of noradrenergic LC neurons (Stiene-Martin and Hauser, 1993; Stiene-Martin et al., 1993). Such functional relationships could be particularly significant during development or in drug-induced synaptic plasticity.

\section{REFERENCES}

Aghajanian GK, Wang Y-Y (1986) Pertussis toxin blocks the outward currents evoked by opiate and alpha-2 agonists in locus coeruleus neurons. Brain Res 371:390-394.

Alreja M, Aghajanian GK (1993) Opiates suppress a resting sodiumdependent inward current and activate an outward potassium current in locus coeruleus neurons. J Neurosci 13:3525-3532.

Aoki C, Pickel VM (1992) C-terminal tail of beta-adrenergic receptors: immunocytochemical localization within astrocytes and their relation to catecholaminergic neuron on the nucleus tractus solitarii and area postrema. Brain Res 571:35-49.

Armstrong DM, Pickel VM, Joh T, Reis DJ, Miller RJ (1981) Immunocytochemical localization of catecholamine synthesizing enzymes and 
neuropeptides in area postrema and medial nucleus tractus solitarius of rat brain. J Comp Neurol 196:505-517.

Arvidsson U, Riedl M, Chakrabarti S, Lee JH, Nakano AH, Dado RJ, Loh HH, Law PY, Wessendorf MW, Elde R (1995) Distribution and targeting of a mu-opioid receptor (MOR1) in brain and spinal cord. J Neurosci 15:3328-3341.

Aston-Jones G, Shipley MT, Chouvet G, Ennis M, Van Bockstaele E, Pieribone V, Shiekhattar R, Akaoka H, Drolet G, Astier B (1991) Afferent regulation of locus coeruleus neurons: anatomy, physiology and pharmacology. Prog Brain Res 88:47-75.

Atweh SF, Kuhar MJ (1977) Autoradiographic localization of opiate receptors in rat brain. III. The telencephalon. Brain Res 134:393-405.

Beitner DB, Duman RS, Nestler EJ (1989) A novel action of morphine in the rat locus coeruleus: persistent decrease in adenylate cyclase. Mol Pharmacol 35:559-564.

Bird SJ, Kuhar MJ (1977) Iontophoretic application of opiates to the locus coeruleus. Brain Res 122:523-533.

Carlin RK, Grab DJ, Cohen RS, Siekevitz P (1980) Isolation and characterization of postsynaptic densities from various brain regions: enrichment of different types of postsynaptic densities. J Cell Biol 86:831-832.

Chan J, Aoki C, Pickel VM (1990) Optimization of differential immunogold-silver and peroxidase labeling with maintenance of ultrastructure in brain sections before plastic embedding. J Neurosci Methods 33:113-127.

Cheng PY, Moriwaki A, Wang JB, Uhl GR, Pickel VM 1996 Ultrastructural localization of mu-opioid receptor immunoreactivity in the superficial layers of the rat cervical spinal cord: abundant extrasynaptic immunoreactivity and proximity to $\mathrm{leu}^{5}$-enkephalin labeled neurons. Brain Res, in press.

Drolet G, Van Bockstaele EJ, Aston-Jones G (1992) Robust enkephalin innervation of the locus coeruleus from the rostral medulla. J Neurosci 12:3162-3174.

Duman RS, Tallman JF, Nestler EJ (1988) Acute and chronic opiate regulation of adenylate cyclase in brain: specific effects in locus coeruleus. J Pharmacol Exp Ther 246:1033-1039.

Fallon JH, Leslie FM (1986) Distribution of dynorphin and enkephalin peptides in the rat brain. J Comp Neurol 249:293-336.

Gray EG (1959) Axosomatic and axo-dendritic synapses of the cerebral cortex: an electron microscopic study. J Anat 93:420-433.

Grzanna R, Molliver ME (1980) The locus coeruleus in the rat: an immunohistochemical delineation. Neuroscience 5:21-40.

Guitart X, Nestler EJ (1989) Identification of morphine- and cyclic AMP-regulated phosphoproteins (MARPPs) in the locus coeruleus and other regions of rat brain: regulation by acute and chronic morphine. J Neurosci 9:4371-4387.

Guitart X, Nestler EJ (1993) Second messenger and protein phosphorylation mechanisms underlying opiate addiction: studies in the rat locus coeruleus. Neurochem Res 18:5-13.

Harris GC, Williams JT (1991) Transient homologous $\mu$-opioid receptor desensitization in rat locus coeruleus neurons. J Neurosci 11:2574-2581.

Hsu SM, Raine L, Fanger H (1981) Use of avidin-biotin peroxidase complex $(\mathrm{ABC})$ in immunoperoxidase techniques: a comparison between $\mathrm{ABC}$ and unlabeled antibody (PAP) procedures. J Histochem Cytochem 29:557-580.

Khachaturian H, Lewis ME, Watson SJ (1983) Enkephalin systems in diencephalon and brainstem of the rat. J Comp Neurol 220:310-320.

Leranth C, Pickel VM (1989) Electron microscopic pre-embedding double immunostaining methods. In: Tract-tracing methods 2, recent progress (Heimer L, Zaborsky L, eds), pp 129-172. New York: Plenum.

Mansour A, Fox CA, Akil H, Watson SJ (1995) Opioid-receptor mRNA expression in the rat CNS: anatomical and functional implications. Trends Neurosci 18:22-29.

Nestler EJ, Erdos JJ, Terwilliger T, Duman RS, Tallman JF (1989a) Regulation of $\mathrm{G}$ proteins by chronic morphine in the rat locus coeruleus. Brain Res 476:230-239.

Nestler EJ, Terwilliger R, Beitner D (1989b) Regulation by chronic clonidine of adenylate cyclase and cyclic AMP-dependent protein kinase in the rat locus coeruleus. Life Sci 45:1073-1080.

North RA, Williams JT (1985) On the potassium conductance increase by opioids in rat locus coeruleus neurons. J Physiol (Lond) 364:265-280.

North RA, Williams JT, Surprenant A, Christie MJ (1987) Mu and delta receptors belong to a family of receptors that are coupled to potassium channels. Proc Natl Acad Sci USA 84:5487-5491.
Nusser Z, Roberts JDB, Baude A, Richards JG, Somogyi P (1995) Relative densities of synaptic and extrasynaptic GABAa receptors on cerebellar granule cells as determined by a quantitative immunogold method. J Neurosci 15:2948-2960.

Pepper CM, Henderson G (1980) Opiates and opioid peptides hyperpolarize locus coeruleus neurons in vitro. Science 209:394-396.

Peters A, Palay SL, Webster H de F (1991) The fine structure of the nervous system. New York: Oxford UP.

Pickel VM, Joh TH, Reis DJ, Leeman SE, Miller RJ (1979) Electron microscopic localization of substance $\mathrm{P}$ and enkephalin in axon terminals related to dendrites of catecholaminergic neurons. Brain Res 160:387-400.

Pickel VM, Chan J, Veznedaroglu E, Milner TA (1995) Neuropeptide Y and dynorphin immunoreactive large dense core vesicles are strategically localized for presynaptic modulation in the hippocampal formation and substantia nigra. Synapse 19:160-169.

Rodriguez-Boulan E, Powell SK (1992) Polarity of epithelial and neuronal cells. Annu Rev Cell Biol 8:395-427.

Schwartz JP, Nishiyama N, Wilson D, Taniwaki T (1994) Receptormediated regulation of neuropeptide gene expression in astrocytes. Glia 11:185-190.

Shipley MT, Fu L, Ennis M, Liu WL, Aston-Jones G (1996) Dendrites of locus coeruleus neurons extend preferentially into two pericoerulear zones. J Comp Neurol 363:56-68.

Simantov R, Kuhar MJ, Uhl GR, Snyder SH (1977) Opioid peptide enkephalin: immunohistochemical mapping in rat central nervous system. Proc Natl Acad Sci USA 74:2167-2171.

Stiene-Martin A, Hauser KF (1993) Morphine suppresses DNA synthesis in cultured murine astrocytes from cortex, hippocampus and striatum. Neurosci Lett 157:1-3.

Stiene-Martin A, Mattson MP, Hauser KF (1993) Opiates selectively increase intracellular calcium in developing type- 1 astrocytes: role of calcium in morphine induced morphologic differentiation. Dev Brain Res 76:189-196.

Surratt CK, Johnson PS, Moriwaki A, Seidleck BK, Blaschak CJ, Wang JB, Uhl GR (1994) Mu opiate receptor: charged transmembrane domain amino acids are critical for agonist recognition and intrinsic activity. J Biol Chem 32:20548-20553.

Svingos A, Pickel VM, Moriwaki A, Wang JB, Uhl GR 1996 Ultrastructural immunocytochemical localization of mu-opiate receptor in the rat nucleus accumbens: extrasynaptic plasmalemmal distribution and association with leucine ${ }^{5}$-enkephalin. J Neurosci, in press.

Swanson LW (1976) The locus coeruleus: a cytoarchitectonic, golgi and immunohistochemical study in the albino rat. Brain Res 110:39-56.

Swanson LW (1992) Brain maps: structure of the rat brain. New York: Elsevier.

Tempel A, Zukin RS (1987) Neuroanatomical patterns of the mu, delta, and kappa opioid receptors of rat brain as determined by quantitative in vitro autoradiography. Proc Natl Acad Sci USA 84:4308-4312.

Valtschanoff JG, Phend KD, Bernardi PS, Weinberg RJ, Rustioni A (1994) Amino acid immunocytochemistry of primary afferent terminals in the rat dorsal horn. J Comp Neurol 346:237-252.

Van Bockstaele EJ, Pickel VM (1993) Ultrastructure of serotoninimmunoreactive terminals in the core and shell of the rat nucleus accumbens: cellular substrates for interactions with catecholamine afferents. J Comp Neurol 334:603-617.

Van Bockstaele EJ, Sesack SR, Pickel VM (1994) Dynorphinimmunoreactive terminals in the rat nucleus accumbens: cellular sites for modulation of target neurons and interactions with catecholamine afferents. J Comp Neurol 341:1-15.

Van Bockstaele EJ, Branchereau P, Pickel VM (1995) Morphologically heterogenous met-enkephalin terminals form synapses with tyrosine hydroxylase-containing dendrites in the rat nucleus locus coeruleus. J Comp Neurol 363:423-438.

Wang JB, Imai Y, Eppler CM, Gregor P, Spivak CE, Uhl GR (1993) Mu opiate receptor: cDNA cloning and expression. Proc Natl Acad Sci USA 90:10230-10234.

Williams JT, Egan TM, North RA (1982) Enkephalin opens potassium channels on mammalian central neurons. Nature 299:74-77.

Zhu PC, Thureson-Klein AK, Klein RL (1986) Exocytosis from large dense cored vesicles outside the active synaptic zones of terminals within the trigeminal subnucleus caudalis: a possible mechanism for neuropeptide release. Neuroscience 19:43-54. 